\title{
Study of placentation and maternal and fetal outcomes in cases of 2 or more caesarean sections
}

\author{
Supriya Poonia*, Meena Naresh Satia, Nidhi Bang
}

Department of Obstetrics and Gynaecology, King Edward Memorial Hospital, Mumbai, India

Received: 27 May 2016

Accepted: 15 June 2016

\section{*Correspondence:}

Dr. Supriya Poonia,

E-mail: supriyachaudhary01@gmail.com

Copyright: () the author(s), publisher and licensee Medip Academy. This is an open-access article distributed under the terms of the Creative Commons Attribution Non-Commercial License, which permits unrestricted non-commercial use, distribution, and reproduction in any medium, provided the original work is properly cited.

\section{ABSTRACT}

Background: The CS epidemic is a reason for immediate concern and there is increase in repeat CS as well these days. The secondary increase in repeat CS delivery has been associated with increase in CS complications particularly increase in complications associated with abnormal placentation.

Methods: It is a Prospective observational study which was conducted at a tertiary care centre over a period of 18 months with a sample size of 60 patients. Patients with two or more previous CS irrespective of parity index, gestational age, previous vaginal delivery or vaginal birth after CS, associated medical or surgical problems were included in the study. Intra-partum, postpartum complications, abnormal placentation, maternal and perinatal outcomes associated with previous 2 CS were studied. Any case less than 2 CS were excluded.

Results: In this study, radiologically, 50 patients had no abnormality. 7 patients had placenta previa, 2 patients had placenta percreta and 1 patient had placenta previa with placenta accreta. These included abnormal placentation diagnosed radiologically by ultrasonography, colour Doppler or MRI. Intra-operatively, 49 patients had normal placentation. 6 patients had placenta previa without any evidence of placental adherence, 3 patients were placenta percreta. 1 patient had placenta previa with placenta percreta and 1 had placenta previa with placenta increta. Statistically significant differences $\mathrm{p}<.05$ was observed in group of normal and abnormal placentation, with respect to type of anesthesia spinal/GA, uterine incision(pfannensteil versus midline and classical), bladder injury, intraoperative blood loss, uterine and internal iliac artery ligation, obstetric hysterectomy, placenta kept in situ, surgical site infections, neonatal resuscitation required and NICU admissions.

Conclusions: The incidences of abnormal placentation have increased with the rise in previous two CS Also the maternal and perinatal morbidity and mortality increases with history of previous two CS.

Keywords: Placentation, Previous two CS, Maternal and perinatal complications

\section{INTRODUCTION}

Amongst the many advances in the obstetrics practice, one of the most apparent has been progressive increase in the frequency of caesarean section (CS). CS rates are inexorably rising which has led to the possibility of negative impact on maternal and neonatal health. The CS epidemic is a reason for immediate concern and deserves serious international attention. From the time when childbirth was an event not necessitating medical care to the present times when there are concerns about high caesarean delivery rates, obstetrics has travelled a long way. CS though a widely accepted surgery these days has its own set of complications both for the mother and foetus.

The safety of lower uterine segment technique, the evolution of anaesthetic proficiency, broadening of indications of CS, availability of blood and blood products, powerful and effective antibiotics, advent of fetal heart monitoring, the recognition of foetus as a patient, the possibility of vaginal delivery post CS the 
acceptance of this procedure by women, improvement in surgical techniques and operative skills, advances in neonatal intensive care, have characterized the evolution of this procedure in $21^{\text {st }}$ century. With the increase in primary CS there is increase in repeat CS. CS accounts for one of the major indications for CS. In India it ranges from 8.48 to $41.9 \%$. $^{1}$ The secondary increase in repeat CS delivery has been associated with increase in the complications particularly those due to abnormal placentation.

Placenta previa, placenta accreta and its subtypes have been associated with increasing frequency with repeated childbirths. While a lot of emphasis has been put on previous one CS, the focus of this study is to check for abnormal placentation like placenta previa, accreta, increta or percreta and maternal and fetal outcomes and complications in cases of two or more previous CS.

\section{METHODS}

It is a prospective observational study which was conducted in a tertiary care centre over a period of 18 months from May 2014 to October 2015 with a sample size of 60 patients. Patients with two or more previous CS irrespective of parity index, gestational age, previous vaginal delivery or vaginal birth after CS, associated medical or surgical problem, in antenatal outpatient department and emergency patients were included in the study.

A questionnaire was developed that included detailed information regarding maternal age, parity, gestational age, registration status, menstrual and obstetrics history, course of present pregnancy, any medical or surgical history including curettage or myomectomy. Examination findings and relevant investigations including USG obstetrics, with special mention on placental localization, if any abnormal placentation likes placenta previa or adherent placenta then USG colour doppler and MRI findings were documented.

Patient diagnosed with the help of radiological investigation like USG/colour doppler/MRI or confirmed intra-operatively, were taken as abnormal placentation as placenta previa, morbidly adherent placenta like placenta accreta, placenta increta, placenta percreta. Vascular interventional radiology procedure like balloon placement and uterine/internal iliac artery embolization done was documented. Any adjuvant therapy like injection methotrexate given and beta-hCG levels in such cases was followed up till B-hCG reached the threshold value or patient expelled out the placenta or underwent any surgical intervention. Patient were followed up till discharge from hospital except in case of retained placenta where the follow up was till B-hCG level reached the threshold value, or patient expelled out the placenta or underwent any surgical intervention.
Statistical tool used was SPSS 16.0 version. Descriptive data collected was analyzed by mean and standard deviation proportions and the inferential data was by Pearson's Chi square test and Fischer's exact test. Statistical significance was considered when p-value was $<.05$.

\section{RESULTS}

In the study group of 60 patients, 52 patients had previous $2 \mathrm{CS}$ and 8 previous $3 \mathrm{CS}$. 59 patients had delivered by $C S$ and 1 delivered vaginally due to inadvertent condition. Mean age group of patients in this study was 26.4 years. 39 patients were registered (had at least one OPD visit at our institute), 16 were referred and 5 were unregistered. Majority $68 \%$ of the patients had their first visit in third trimester. These included patients who were referred to the institute at the time of delivery. $30 \%$ patients visited in second trimester and only one patient had registered in first trimester of pregnancy. 20 patients had past history of curettage and 2 had myomectomy done in past. 18 patients required admission to antenatal ward: 9 for anaemia, 4 for preterm labour, 2 for bleeding per vaginum and 3 patients were admitted for medical causes. $61 \%$ patients were delivered between 37-39.6 weeks of gestation, $30 \%$ between 32 to 36.6 weeks, and $7 \%$ between 28 to 32 weeks of gestation. For $2 \%$, unregistered patient CS was done after 40 weeks.

10 patients were diagnosed preoperatively radiologically whereas additional one patient was diagnosed intraoperatively. Intra-operatively, 6 patients had placenta previa without adherence, 3 placenta percreta, and 1 patient previa with percreta and 1 with placenta previa with increta. $65 \%$ of patients had tubal ligation done along with caesarean section whereas $35 \%$ didn't undergo tubal ligation. Amongst these $35 \%$ patients, intrauterine copper-T device was inserted for $4 \%$ patients and obstetrics hysterectomy was required in $7 \%$ patients.

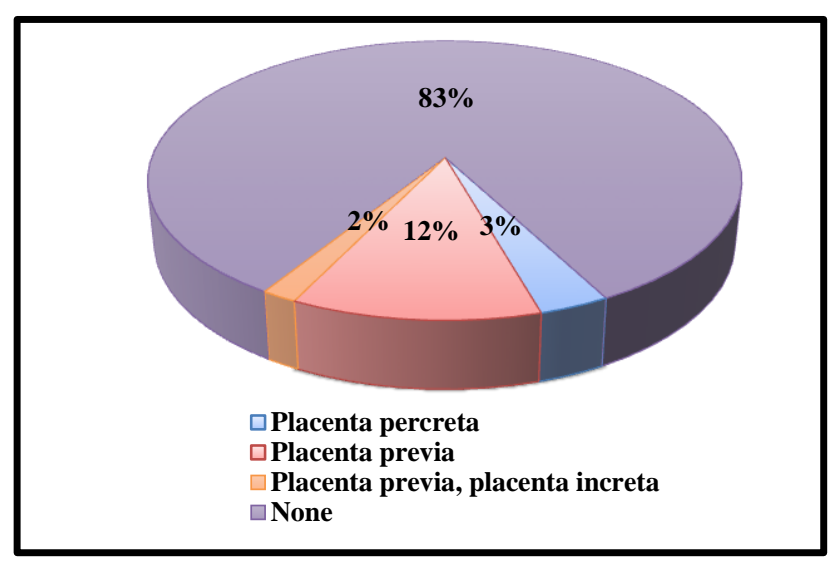

Figure 1: Distribution of study group based on radiological placental abnormality. 


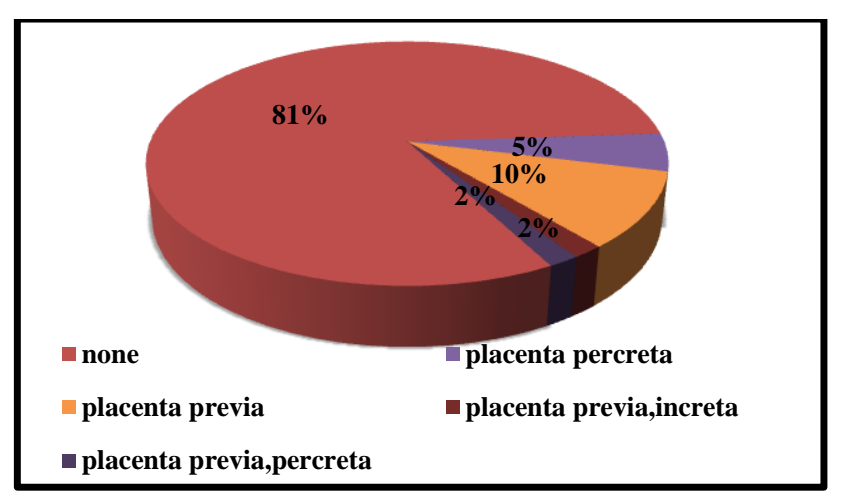

Figure 2: Distribution of study group based on intraoperative placental abnormality.

Table 1: The distribution of patients based on abnormal placentation radiologically and intraoperatively.

\begin{tabular}{|lll|}
\hline Placentation & $\begin{array}{l}\text { Radio-logically } \\
\text { diagnosed }\end{array}$ & $\begin{array}{l}\text { Intra-operatively } \\
\text { diagnosed }\end{array}$ \\
\hline Normal placentation & $83 \%(50)$ & $81 \%(49)$ \\
\hline $\begin{array}{l}\text { Placenta previa without } \\
\text { adherent placenta }\end{array}$ & $12 \%(7)$ & $10 \%(6)$ \\
\hline Placenta percreta & $3 \%(2)$ & $5 \%(3)$ \\
\hline $\begin{array}{l}\text { Placenta previa with } \\
\text { placenta percreta }\end{array}$ & $2 \%(1)$ \\
\hline $\begin{array}{l}\text { Placenta previa with } \\
\text { placenta increta }\end{array}$ & $2 \%(1)$ & $2 \%(1)$ \\
\hline
\end{tabular}

Table 2: Demographic and clinical features are divided based on normal and abnormal placentation.

\begin{tabular}{|c|c|c|c|}
\hline & $\begin{array}{l}\text { Normal } \\
\text { placentation }\end{array}$ & $\begin{array}{l}\text { Abnormal } \\
\text { placentation }\end{array}$ & $\begin{array}{l}\text { P Value }(<.05 \\
\text { significant })\end{array}$ \\
\hline $\begin{array}{l}\text { Mean Age } \\
\text { (years) }\end{array}$ & 26.6 & 26.4 & \\
\hline \multicolumn{3}{|c|}{ Gestation (weeks) at delivery } & 0.146 \\
\hline $28-32$ & $2(4.1 \%)$ & $2(18.2 \%)$ & \\
\hline $32-36.6$ & $13(26.5 \%)$ & $5(45.5 \%)$ & \\
\hline $37-39.6$ & $33(37.3 \%)$ & $4(36.4 \%)$ & \\
\hline$>40$ & $1(2 \%)$ & $0(0 \%)$ & \\
\hline $\begin{array}{l}\text { Hospital } \\
\text { stay(days) }\end{array}$ & 7 & 10.4 & \\
\hline $\begin{array}{l}\text { Neonate } \\
\text { birth } \\
\text { weight } \\
(<2.5 \mathrm{~kg})\end{array}$ & $21(42.5 \%)$ & $6(54.5 \%)$ & .0521 \\
\hline
\end{tabular}

Table 3: Operative details of patients based on division of normal and abnormal placentation.

\begin{tabular}{|lllc|}
\hline Type of CS & $\begin{array}{l}\text { Normal } \\
\text { placentation }\end{array}$ & $\begin{array}{l}\text { Abnormal } \\
\text { placentation }\end{array}$ & $\begin{array}{c}\text { P Value(<.05 } \\
\text { significant) }\end{array}$ \\
\hline Elective & $20(40.8 \%)$ & $2(18.2 \%)$ & 0.306 \\
\hline Emergency & $28(59.2 \%)$ & $9(81.8 \%)$ & \\
\hline \multicolumn{2}{|l}{ Type of anaesthesia } & & 0.017 \\
\hline Spinal & $6(54.5 \%)$ & $5(45.5 \%)$ & \\
\hline General & $43(87.8 \%)$ & $5(10.2 \%)$ & \\
\hline Skin & & & 0.658 \\
\hline
\end{tabular}

\begin{tabular}{|c|c|c|c|}
\hline incision & & & \\
\hline Pfannensteil & $28(57.1 \%)$ & $5(45.5 \%)$ & \\
\hline $\begin{array}{l}\text { Vertical } \\
\text { midline }\end{array}$ & $20(40.8 \%)$ & $6(54.5 \%)$ & \\
\hline $\begin{array}{l}\text { Anterior } \\
\text { abdominal } \\
\text { wall } \\
\text { adhesions }\end{array}$ & $6(54.5 \%)$ & $14(28.6 \%)$ & .099 \\
\hline Uterine incisi & & & .000 \\
\hline $\begin{array}{l}\text { Lower } \\
\text { segment }\end{array}$ & $49(100 \%)$ & $7(63.6 \%)$ & \\
\hline Classical & $0(0 \%)$ & $4(36.4 \%)$ & \\
\hline $\begin{array}{l}\text { Intervention } \\
\text { al radiology } \\
\text { (balloon } \\
\text { placement) }\end{array}$ & & $4(7 \%)$ & \\
\hline $\begin{array}{l}\text { Uterine } \\
\text { artery }\end{array}$ & & $1(2 \%)$ & \\
\hline $\begin{array}{l}\text { Internal iliac } \\
\text { artery }\end{array}$ & & $3(5 \%)$ & \\
\hline
\end{tabular}

Table 4: Complications associated with cases of normal and abnormal placentation.

\begin{tabular}{|llll|}
\hline & Normal & Abnormal & $\begin{array}{l}\text { P value }(<.05 \\
\text { significant }\end{array}$ \\
\hline $\begin{array}{l}\text { Uterine } \\
\text { dehiscence/ } \\
\text { rupture }\end{array}$ & $2(4.1 \%)$ & $1(9.1 \%)$ & .491 \\
\hline Bladder injury & $4(36.4 \%)$ & $0(0 \%)$ & .000 \\
\hline $\begin{array}{l}\text { Intraoperative } \\
\text { blood loss }>1 \\
\text { litre }\end{array}$ & $40(81.6 \%)$ & $9(18.4 \%)$ & .011 \\
\hline $\begin{array}{l}\text { Uterine artery } \\
\text { ligation }\end{array}$ & $4(9.2 \%)$ & $5(45.5 \%)$ & .002 \\
\hline $\begin{array}{l}\text { Internal iliac } \\
\text { ligation }\end{array}$ & $2(18.2 \%)$ & $1(2.0 \%)$ & .026 \\
\hline $\begin{array}{l}\text { Obstetrics } \\
\text { hysterectomy }\end{array}$ & $2(18.2 \%)$ & $1(2.0 \%)$ & .026 \\
\hline Placenta in situ & $0(0 \%)$ & $2(18.2 \%)$ & .002 \\
\hline ICU admission & $2(4.1 \%)$ & $1(9.1 \%)$ & .462 \\
\hline Shock & $0(0 \%)$ & $1(9.1 \%)$ & .033 \\
\hline $\begin{array}{l}\text { Surgical site } \\
\text { infection }\end{array}$ & $7(14.3 \%)$ & $6(54.5 \%)$ & .003 \\
\hline $\begin{array}{l}\text { Neonatal } \\
\text { resuscitation }\end{array}$ & $5(10.2 \%)$ & $4(36.4 \%)$ & .028 \\
\hline $\begin{array}{l}\text { NICU } \\
\text { admission }\end{array}$ & $7(14.3 \%)$ & $5(45.5 \%)$ & .020 \\
\hline
\end{tabular}

Statistically significant differences $\mathrm{p}<.05$ was observed in group of normal and abnormal placentation with respect to type of anaesthesia (spinal versus general), uterine incision (pfannensteil versus midline and classical), bladder injury, intraoperative blood loss, uterine and internal iliac artery ligation, obstetric hysterectomy, placenta kept in situ, surgical site infections, neonatal resuscitation required and NICU admissions.

The differences were not statistically significant in anterior abdominal wall incision and adhesions, uterine 
dehiscence and rupture, ICU admissions and neonatal birth weight.

\section{DISCUSSION}

Our data evaluates 60 women with previous two or more Caesarean section for their placentation with maternal and fetal outcomes. Major strength of this dissertation was that this being a prospective study, entire antenatal course since first registration to delivery, radiological data, intraoperative and postoperative complications was available for records. Most of the similar studies were retrospective studies.

In this study, there was one case which was not diagnosed antenatally and intra-operatively was found to be placenta percreta and another one which was antenatlly diagnosed to be placenta previa and intraoperatively was associated with placenta percreta.

Table 6: Comparative statics of various important parameters.

\begin{tabular}{|c|c|c|c|}
\hline Other studies & $\begin{array}{l}\text { Parametres } \\
\text { studied }\end{array}$ & $\begin{array}{l}\text { Incidence } \\
\text { of other } \\
\text { studies }\end{array}$ & $\begin{array}{l}\text { Present } \\
\text { Study }\end{array}$ \\
\hline & $\begin{array}{l}\text { Abnormal } \\
\text { placentation }\end{array}$ & & \\
\hline \multirow[t]{2}{*}{${\text { Usta IM et } \mathrm{al}^{2}}^{2}$} & Placenta previa & $0.33 \%$ & $12 \%$ \\
\hline & $\begin{array}{l}\text { Placenta } \\
\text { increate }\end{array}$ & $1.18-9.3 \%$ & $2 \%$ \\
\hline Serena WU et $\mathrm{al}^{3}$ & Placenta accreta & $0.18 \%$ & $0 \%$ \\
\hline Sobande $\mathrm{A}$ et $\mathrm{al}^{4}$ & Placenta previa & $3.4 \%$ & $12 \%$ \\
\hline \multirow[t]{2}{*}{ Silver $\mathrm{RM}$ et $\mathrm{al}^{5}$} & $\begin{array}{l}\text { Placenta percreta } \\
\text { in placenta previa }\end{array}$ & $40 \%$ & $10 \%$ \\
\hline & $\begin{array}{l}\text { Uterine } \\
\text { dehiscence/ } \\
\text { rupture }\end{array}$ & & \\
\hline \multirow[t]{2}{*}{ Nisenbalt $\mathrm{V}$ et $\mathrm{al}^{8}$} & $\begin{array}{l}\text { Uterine } \\
\text { dehiscence }\end{array}$ & $1.1 \%$ & $6.6 \%$ \\
\hline & Uterine rupture & $3 \%$ & $5 \%$ \\
\hline \multirow[t]{2}{*}{ Rashid $\mathrm{M}$ et $\mathrm{al}^{6}$} & $\begin{array}{l}\text { Uterine } \\
\text { dehiscence }\end{array}$ & $1 \%$ & \\
\hline & Uterine rupture & $2 \%$ & \\
\hline \multirow[t]{2}{*}{ Cook et $\mathrm{al}^{9}$} & $\begin{array}{l}\text { Uterine } \\
\text { dehiscence }\end{array}$ & $2 \%$ & \\
\hline & $\begin{array}{l}\text { Bladder/bowel } \\
\text { injury }\end{array}$ & & \\
\hline \multirow[t]{2}{*}{ Silver $\mathrm{RM}$ et $\mathrm{al}^{5}$} & Bladder injury & $0.28 \%$ & $6.6 \%$ \\
\hline & Bowel injury & $0.02 \%$ & $0 \%$ \\
\hline \multirow[t]{2}{*}{ Nisenbalt $\mathrm{V}$ et $\mathrm{al}^{8}$} & $\begin{array}{l}\text { Bladder/bowel } \\
\text { injury }\end{array}$ & $0 \%$ & \\
\hline & $\begin{array}{l}\text { Maternal } \\
\text { mortality }\end{array}$ & & \\
\hline Silver $\mathrm{RM}$ et $\mathrm{al}^{5}$ & & $0.55 \%$ & $2 \%$ \\
\hline Rashid $\mathrm{M}$ et $\mathrm{al}^{6}$ & & $0.3 \%$ & \\
\hline
\end{tabular}

The higher incidence of abnormal placentation in our study could be attributed to the fact that ours being a tertiary care centre, patients were referred to our institute.
In our study, interventional radiology procedure was done in $7 \%$ of patients of which preoperative Internal iliac artery balloon placement was done in $5 \%$ of cases and uterine artery balloon placement in $2 \%$ of cases. The rationale of inserting intravascular balloon catheters is to decrease blood flow to the uterus and to reduce blood loss.

In our study, $55 \%$ patients were given pfannensteil incision and $43 \%$ patients were operated via vertical midline incision. As per study by Rashid M et al, $79 \%$ were given pfannensteil incision and $21 \%$ had vertical midline. ${ }^{6}$ As per study by Sobande A et al $46 \%$ had pfannensteil incision and $54 \%$ had vertical midline incision. $^{4}$

In this study, $91 \%$ of patients LSCS was done. $7 \%$ of patients were operated with classical CS. In the study conducted by Rashid $\mathrm{M}$ et al, no patient required classical uterine incision, in the group of patients with third or more caesarean sections. ${ }^{6}$

$33.33 \%$ of patients in this study had intraoperative abdominal wall adhesions. As per Tulandi $\mathrm{T}$ et al $24.4 \%$ had adhesions after 2 CS and $42.8 \%$ had adhesions after 3 $\mathrm{CS}^{7}$ As per Nisenbalt $\mathrm{V}$ et al $34.6 \%$ had adhesions. Both studies had adhesions similar to our study. ${ }^{8}$ Adhesions formation is not unexpected because repeated surgery may be associated with postoperative infection and subsequent formation.

In our study, uterine artery ligation was done in $15 \%$ of patients, 5\% required internal iliac ligation and similar number required obstetric hysterectomy. As per Rashid $\mathrm{M}$ et al $1 \%$, Nisenbalt $\mathrm{V}$ et al $1.1 \%$ and Silver $\mathrm{M}$ et al $0.90 \%$ required obstetrics hysterectomy. ${ }^{5-8}$ Our study showed higher rates compared to all the above studies.

In our study placenta was kept in situ for 2 patients. Both these patients were successfully managed with methotrexate therapy with no failure cases. In a recent review by Sentilhes et al, conservative management was utilized in 167 cases of placenta accreta/percreta. The failure rate was $22 \%$ and hysterectomy, either primary or delayed, was required mostly for severe haemorrhage. Severe maternal morbidity, including one maternal death, occurred in $6 \%$ of cases. ${ }^{10}$ As per study by AF Hundley, $90 \%$ of women were successfully managed with conservative treatment using methotrexate therapy. ${ }^{11}$

In this study, majority (76.67\%) of patients lost blood up to 1.0 liter. In $15 \%$ of patients blood loss was from 1.0 to 1.5 liters, $6.67 \%$ blood loss was from 1.5 to 2.0 liters. Only one patient lost $>2.5$ liters of blood. As per Rashid $\mathrm{M}$ et al $6 \%$ cases, Nisenbalt $\mathrm{V}$ et al $7.9 \%$ had blood loss more than 1 litres. $^{6,8}$ In our study blood loss was more compared to other studies. In this study, one patient had gone into hemorrhagic shock. She was an unregistered patient who was admitted with complaints of bleeding per vaginum and had undergone emergency caesarean section for bleeding placenta previa. She was transfused with eight units of packed red blood cells. 
A total of 13 patients $(22 \%)$ had surgical site infections in our study group. $54.5 \%$ of cases with abnormal placentation had surgical site infection and $14.3 \%$ of normal placentation. Majority of them required $(77 \%)$ required secondary suturing and $23 \%$ had healed with secondary intention. In study by Sobande A et al $3.4 \%$ patients had surgical site infections. ${ }^{4}$ Our study shows much higher rate compared to this. This could be due to high prevalence of anaemia, poor nutritional status, higher intraoperative blood loss and medical/surgical high risk patients like diabetes mellitus, gestational diabetes mellitus etc. In this study, average duration of stay in hospital, was 7.6 days. This is similar to study by Sobande A et al where average duration of hospital stay was 6.8 days. $^{4}$

In my study, mean birth weight was $2.790 \mathrm{kgs}$. This is similar to birth weights by Sobande A and Rashid M et al where mean birth weight were $2.972 \mathrm{kgs}$ and $2.966 \mathrm{kgs}$ respectively. ${ }^{4,6}$ Birth weights were lower compared to study by Macones GA and Cahill AG et al in which mean birth weight was $3.392 \mathrm{kgs}$ and $3.046 \mathrm{kgs}$ respectively. ${ }^{12,13}$ Lower birth weight could be explained by the fact that the patients in our country are constitutionally small as compared to their western counterparts along with anaemia, preeclampsia, and abnormal placentation.

In our study, 9 neonates $(15 \%)$ required resuscitation. $20 \%$ of neonates in our study required neonatal intensive care unit (NICU) admissions. In study by Rashid M et al $4 \%$ required resuscitation and $20 \%$ NICU admission. ${ }^{6}$ The NICU admission rates were similar to this study. In our study, $3.33 \%$ were neonates born as fresh still births (FSB), 5\% had neonatal deaths. The FSB rates were similar to study by Sobande A et al which were $3.4 \%$. Neonatal deaths were higher compared to Rashid $\mathrm{M}$ et al which were $1 \% .^{6}$

This escalated number of previous CS stresses on the essence of early antenatal registration at a tertiary care centre with round the clock availability of obstetrician, neonatologist, and anesthetist. By embracing these practices going forward, hopefully we can control the rising rate of previous two caesarean section and mitigate the risk inherent in the performance of caesarean delivery. Women should be counselled regarding the long-term consequences including morbidity and mortality associated with multiple caesarean delivery and complications associated with abnormal placentation. Multifaceted strategies, based on research and detailed feedback, are advised to improve clinical practice and effectively reduce caesarean section rate.
Funding: No funding sources Conflict of interest: None declared

Ethical approval: The study was approved by the Institutional Ethics Committee

\section{REFERENCES}

1. Chhabra S, Arora G. Delivery in women with previous Caesarean section. J Obstet Gynecol India. 2006;56(4):304-7.

2. Serena WU, Kocherginsky M, Judith U, Hibbard MD. Abnormal placentation: twenty year analysis. ACOG. 2005; 192:1458-61.

3. Usta IM, Hobeika EM, Abu- Musa AA, Gabriel GE, Nassar AH. Placenta previa-accreta: risk factors and complications. Am J Obstet Gynecol. 2005;193(3pt2):1045

4. Sobande A, Eskandar M. Multiple repeat caesarean sections: complications and outcomes. Canada JOGC. 2006;28(3):193-7.

5. Silver RM, Landon MB, Rouse DJ, Leveno KJ, Spong CY, Thom EA, et al: Maternal morbidity associated with multiple Caesarean deliveries. Obstet Gynecol. 2006;207:1226.

6. Rashid M, Rashid RS. Higher order repeat caesarean sections: how safe are five or more? RCOG. 2004;111:1090-4.

7. Tulandi T, Agdi M, Zarei A, Miner L, Sikirica V. Adhesion development and morbidity after repeat cesarean delivery. Am J Obstet Gynecol. 2009;201:56e1-6.

8. Nisenbalt V, Barak S, Griness OB, Degani S, Ohel $\mathrm{G}$, Gonen R, et al. Maternal complications associated with multiple caesarean deliveries. Obstet Gynecol. 2006;108:21-6.

9. Cook J, Javis S, Knight M, Dhanjal MK. Multiple repeats caesarean sectionin the UK: incidence and consequences to the mother and child. A national prospective, cohort study. BJOG. 2013;120(1):85-91.

10. Sentilhes L, Ambroselli C, Kayem G. Maternal outcome after conservative treatment of placenta accreta. Obstetrics and Gynecology. 2010;115(3):526-34.

11. Hundley AF, Lee P. Managing placenta accreta. OBG management. 2002;8:18-33.

12. Macones GA, Cahil A, Pare E, Stamilio DM, Ratcliffe S, Stevens E, et al. Obstetrics outcomes in women with two prior caesarean deliveries: Is vaginal birth after caesarean delivery a viable option? Am J Obstet Gynecol. 2005;192:1223-9.

13. Cahill AG, Tuuli M, Odibo AO, Stamilio DM, Macones DA. Vaginal birth after caesarean for women with three or more prior caesareans: assessing safety and success. BJOG. 2009;117:4228.

Cite this article as: Poonia S, Satia MN, Bang N.

Study of placentation and maternal and fetal outcomes in cases of 2 or more caesarean sections. Int J Reprod Contracept Obstet Gynecol 2016;5:2402-6. 